\title{
A pertinência de uma faculdade de Direito Canônico na Região Amazônica
}

The relevance of a faculty of Canon Law in the Amazon Region

A Igreja tem sido desafiada pelo ministério do Papa Francisco a encontrar caminhos mais eficazes e próximos das realidades humanas, para que o anúncio do Evangelho seja uma resposta ao homem hodierno, na diversidade das identidades culturais. Destaca-se, recentemente, todo o ambiente do Sínodo Pan-amazônico.

No artigo "A eclesiologia e a metodologia da ciência canônica" do Dr. Denilson Geraldo ${ }^{2}$, observam-se diversos aspectos da relação entre o método do saber canônico e o do tratado teológico sobre o mistério da Igreja.

Esses dois elementos colocam-nos a questão sobre a pertinência do "ser Igreja" na Pan-Amazônia e o estudo do Direito Canônico, como instrumento de inculturação e missão nesse contexto eclesial específico.

\footnotetext{
${ }^{1}$ Mestrando em Direito Canônico pelo Instituto Superior de Direito Canônico de Santa Catarina (ISDCSC), licenciado em Filosofia pelas Faculdades Integradas do Ipiranga (UNI-FAI), bacharel em Teologia, pela Pontifícia Faculdade de Teologia "Nossa Senhora da Assunção".

2 GERALDO, Denilson. A eclesialidade e a metodologia da ciência canônica. In: REVISTA SCIENTIA CANONICA, v. 2, n. 4, 2019, p. 7-10.
} 
João Paulo II, ao referir-se ao CIC de 1983, afirma que o Código oferecia um roteiro para a vivência da missão eclesial, em profunda fidelidade ao Evangelho, "[...] grande esforço para transferir, para a linguagem canonística, a própria eclesiologia conciliar." 3.

Principalmente sob o Magistério do Papa Francisco, a ciência canônica ganha maiores relevos pastorais, sem, no entanto, perder a compreensão de que o aspecto jurídico da Igreja está em sua natureza, e que o método próprio da canonística é jurídico.

$\mathrm{Na}$ exortação Evangelii Gaudium, Papa Francisco, ainda, nos afirma: "A evangelização está atenta aos progressos científicos para os iluminar (sic) com a luz da fé e da lei natural, tendo em vista procurar que sempre respeitem a centralidade e o valor supremo da pessoa humana em todas as fases da sua existência. Toda a sociedade pode ser enriquecida através deste diálogo que abre novos horizontes ao pensamento e amplia as possibilidades da razão. Também este é um caminho de harmonia e pacificação." ${ }^{\text {. }}$

Ao falar dos povos amazônicos, Francisco afirma: "Eles têm direito ao anúncio do Evangelho, sobretudo àquele primeiro anúncio que se chama querigma e é o anúncio principal, aquele que sempre se tem de voltar a ouvir de diferentes maneiras e aquele que sempre se tem de voltar a anunciar duma forma ou doutra."

Temos diante dos olhos a realidade clara de que devemos aplicar a metodologia jurídico-canônica em cada contexto cultural, pois, em cada realidade, deve existir uma expressividade jurídica eclesial para o autêntico anúncio do Evangelho àquele povo específico. Deduzimos que o processo de inculturação deve realizar-se por meio de uma pastoral que não despreze o elemento jurídico.

Na Exortação Pós-Sinodal "Querida Amazônia", apresenta-se o tema da inculturação da liturgia e dos ministérios: temos, aqui, um

\footnotetext{
${ }^{3}$ IOANNES PAULUS II. Sacrae Disciplinae Leges, n. 18.

${ }^{4}$ FRANCISCO. Exortação apostólica Evangelii gaudium, n. 242.

${ }^{5}$ FRANCISCO. Exortação pós-sinodal “Querida Amazônia”. 02 fev. 2020, n. 64.

${ }^{6}$ Ibid., n. 81-90. 
claro exemplo de como o método jurídico pode auxiliar a pastoral, por uma construção do ordenamento jurídico para a vivência dessa realidade, em um âmbito territorial específico.

Consideremos também que "Há estruturas eclesiais que podem chegar a condicionar um dinamismo evangelizador; de igual modo, as boas estruturas servem quando há uma vida que as anima, sustenta e avalia. Sem vida nova e espírito evangélico autêntico, sem 'fidelidade da Igreja à própria vocação', toda e qualquer nova estrutura se corrompe em pouco tempo."’.

Nesse sentido, na Exortação Pós-Sinodal "Querida Amazônia", papa Francisco afirma: "São João Paulo II ensinou que a Igreja, ao apresentar a sua proposta evangélica, 'não pretende negar a autonomia da cultura. Antes pelo contrário, nutre por ela o maior respeito'. E, dirigindo-se aos indígenas do Continente Americano, lembrou que 'uma fé que não se torna cultura é uma fé, não de modo pleno, acolhida, não inteiramente pensada, nem com fidelidade vivida'. Os desafios das culturas convidam a Igreja a uma 'atitude de prudente sentido crítico, mas também de atenção e confiança." ${ }^{8}$. Percebe-se a grande preocupação de Francisco, em um profundo diálogo com a cultura; nesse caso, amazônica.

Torna-se necessária a adequação do saber canônico, no contexto da evangelização nessa imensa área do Globo. Geraldo ${ }^{9}$ apresenta a normativa para o estudo do direito canônico, partindo dos documentos magisteriais: $1^{\circ}$ definindo o tempo para os ciclos de estudo e os conteúdos próprios do saber jurídico-canônico; $2^{\circ}$ um enfoque histórico; $3^{\circ}$ diálogo profundo com a cultura, com a lógica do que se chama "Igreja em saída", por meio dos critérios do anúncio, do diálogo, com enfoque transdisciplinar, da abertura à internacionalização e concomitante respeito às identidades culturais

\footnotetext{
${ }^{7}$ FRANCISCO. Exortação apostólica Evangelii gaudium, n. 26.

${ }^{8}$ Op. cit., n. 67.

${ }^{9}$ GERALDO, Denilson. A eclesialidade e a metodologia da ciência canônica. In: REVISTA SCIENTIA CANONICA, v. 2, n. 4, 2019, p. 7-10.
} 
dos povos; $4^{\circ}$ por uma exposição científica dos textos legislativos; $5^{\circ}$ construindo o saber diante das exigências deste tempo.

Esse itinerário supracitado, aplicado ao contexto eclesial panamazônico, pode contribuir para a construção da compreensão da missão da Igreja para esses povos. A consequência é a compreensão do ordenamento jurídico eclesial, fiel à tradição canonística universal, concomitantemente com profundas raízes nessa cultura, tornando a missão da Igreja na Pan-Amazônia, expressão pujante da eclesiologia conciliar e do Magistério posterior.

Um instrumento eficaz para esse processo de inculturação, também por meio do saber canônico, seria a ereção de uma Faculdade de Direito Canônico na região em questão. Lembramos que as faculdades, ao longo do processo histórico, evidenciaram-se como aparelhos construtores de ciência e de cultura, como resposta aos contextos nos quais estiveram presentes.

Portanto, percebemos que uma faculdade de Direito Canônico nesse contexto, local e cultural, pode contribuir para que a Igreja seja " $[. .$. encarnada num espaço concreto, dotada de todos os meios de salvação dados por Cristo, mas com um rosto local." ${ }^{10}$. Esse exigente processo evidencia a pertinência do saber canônico na região pan-amazônica e, dessa forma, de uma respectiva faculdade de Direito Canônico.

${ }^{10}$ FRANCISCO. Exortação apostólica Evangelii gaudium, n. 30. 